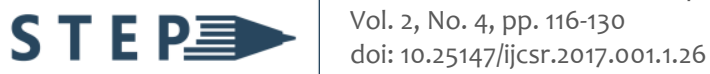 \\ https://stepacademic.net
}

\section{Short Paper \\ HELP2JUANA: Laguna Portal for Violence against Women and Children (VAWC) with E-Reporting and Mapping System}

\author{
Zerah Jane M. Mortel \\ College of Computer Studies, Laguna State Polytechnic University \\ Francis F. Balahadia \\ College of Computer Studies, Laguna State Polytechnic University \\ francis.balahadia@Ispu.edu.ph
}

Date received: October 21, 2018

Date received in revised form: January 4, 2019

Date accepted: January 19, 2019

Recommended citation:

Mortel, Z. J. M. \& Balahadia, F. F. (2018). HELP2JUANA: Laguna portal for violence against women and children (VAWC) with e-reporting and mapping system. International Journal of Computing Sciences Research, 2(4), 116-130. doi: 10.25147/ijcsr.2017.001.1.26

\section{Abstract}

Purpose - The study aims to develop a portal helping victims in Violence against Women and Children (VAWC). This VAWC Portal, map the area where VAWC incident happen. The VAWC portal also have e-reporting feature that will help the Women and Children in reporting when they experience abuse.

Method - The proponents used the Agile Methodology was adopted in the software development. It includes the following stages: Planning; Requirements; Analysis and Design; Testing; Evaluation; and Deployment Then, it also facilitated testing and evaluation, purposive sampling was used to select the respondents. Two sets of questionnaires were developed, one for the residents and another for the government official.

Results - It revealed that Help2Juana has passed the users' evaluation, receiving high scores on User Satisfaction and Attribute of Usability in which Help2Juana web portal can be a tool in the campaign to end violence against women and their children. 
Conclusion - The system meets its objective to provide tool for the VAWC campaign. The high viability of using the Help2Juana web portal scores $t$ from the participating government agencies and the women's community indicate their readiness to adopt and use the system in the said campaign. This positive attitude towards the project can make Help2Juana useful in getting insights for planning VAWC prevention programs and policies, by taking advantage of the empirical data that are provided by the statistical tools integrated into the system.

Recommendations - It recommends that the LGU's and the Women's Community in Laguna consider employing the Help2Juana system in the near future, to test out its capabilities in facilitating and supporting anti-VAWC programs. Other features related to improving government procedures can be added in the process to improve the quality of response to VAWC incidents.

Practical Implications - The Women and Children victim of abuses can easily seek help and report the VAWC incident without shame through the use of Help2Juana. The system can give assistance and awareness regarding to related abuses to women, children and government official especially to R.A. 9262.

Keywords - VAWC, mapping, violence, web portal, e-reporting, women, children

\section{INTRODUCTION}

Violence against Women and Children (VAWC) happens in all parts of the globe and is seen as a major crisis in many societies. VAWC includes various psychological, emotional, financial, cultural, sexual, and socioeconomic abuses towards the victims, and even spiritual cruelties (United Nations, 1993) by family members or relatives. Violence against women is believed to be caused by the uneven power relationship between women and men that promotes the so-called "gender-based violence" (Philippine Commission on Women, 2009). According to a UNICEF statistical report in 2014, of the 120 girls surveyed around the globe, one (1) out of 10 experienced forced sexual contact and the most common perpetrators are current or former husbands, partners, or boyfriend (UNICEF, 2014).

The Philippine Commission on Women (PCW) (PCW, 2009) describes the goal of Gender and Development (GAD) programs as the improvement of outlook and practice that is involved and empowering, reasonable, sustainable, excludes violence, obeys human rights, and supports self-determination and actualization of human abilities. The Philippine National Police (PNP) reported that recorded cases of VAW have increased from 1,100 victims in 1996 to 16,517 in 2013 based on Inter-Agency Council on Violence Against Women and Their Children (IACVAWC, 2004). The situation in the province of Laguna is no different. According to data from the Laguna Police Provincial Office, the 
number of VAWC incidents reported in the recent years is the following: 539 in 2014; 581 in 2015; 446 in 2016; and 1,022 in 2017.

In the CALABARZON region, Galacio (2006) stated that the barangay officials and police officers seem to be not fully oriented with the provisions of Republic Act 9262, or the Anti-Violence Against Women and their Children Act of 2004. The law is clear that in order to end Violence against Women and their Children, the said government agencies should be actively involved. Finding serious intervention for the local government unit like the barangay is one of the significant contents of the RA 9262 said by the Women Working Together to Stop Violence Against Women (WWTSVAW, 2009).

Poor women do not report or seek help from government officials or the police because of shame and lack of resources. The victims also have very limited knowledge of the services offered by the government (WWTSVAW, 2009). Based on a study conducted by the legal management department of San Beda College in 2014, 15.71 percent of the surveyed women were underreporting incidents because of several issues such as embarrassment and blaming themselves for the violence, fear of reprisal from the abusers, and inaccessibility to facilities where one can report incidents of violence, among others. The study also noted that ineffective implementation of the different government interventions and concern about what others will say about the affected individuals being victims of abuse and violence are the main factors why the interventions are not effective (Lobusta et al., 2014).

Other countries have adopted an approach to support VAWC victims. The SASA (Start, Awareness, Support and Action) approach have been successfully implemented by the community members based on Raising Voices organization (e.g. healthcare workers, police) and local cultural and government leaders in the East African countries of Uganda, Malawi, Kenya and Zimbabwe. SASA employs multiple strategies including local activism and media and advocacy strategies, and uses contextually relevant communication and training materials. This approach focuses on orienting the community about the problem and understanding how communities are structured and organized. It also focuses on building confidence through activities, support and encourage. The skills of and connections between community members are strengthened in order to encourage people to support those who are changing or trying to foster change in their community (Evers, 2017).

The objective of this study was to develop a system for VAWC victims to voice out their concerns through integration of SASA, and evaluate User Satisfaction and Usability Attribute of the developed system. It can provide updated news, articles, and activities related to VAWC such as (trainings, seminars, job opportunities, programs). Users can give their complaints, communicate to other victims through forum for them to empower and collaborate in raising awareness to the victims' right. The collected complaints were undergoing for extraction to generate mapping for visualization and produce reports to be send to involve related government agency. 


\section{METHODOLOGY}

\section{Software Development}

Prior to software development, related literature was consulted, benchmarking of related web and mobile applications was conducted, and interviews with Gender and Development (GAD) offices in the fourth district of Laguna were done to aid in the overall conceptualization of the project.

The Agile Methodology was adopted in the software development (Taymor, n.d.). It includes the following stages: (1) Planning; (2) Requirements; (3) Analysis and Design; (4) Testing; (5) Evaluation; and (6) Deployment.

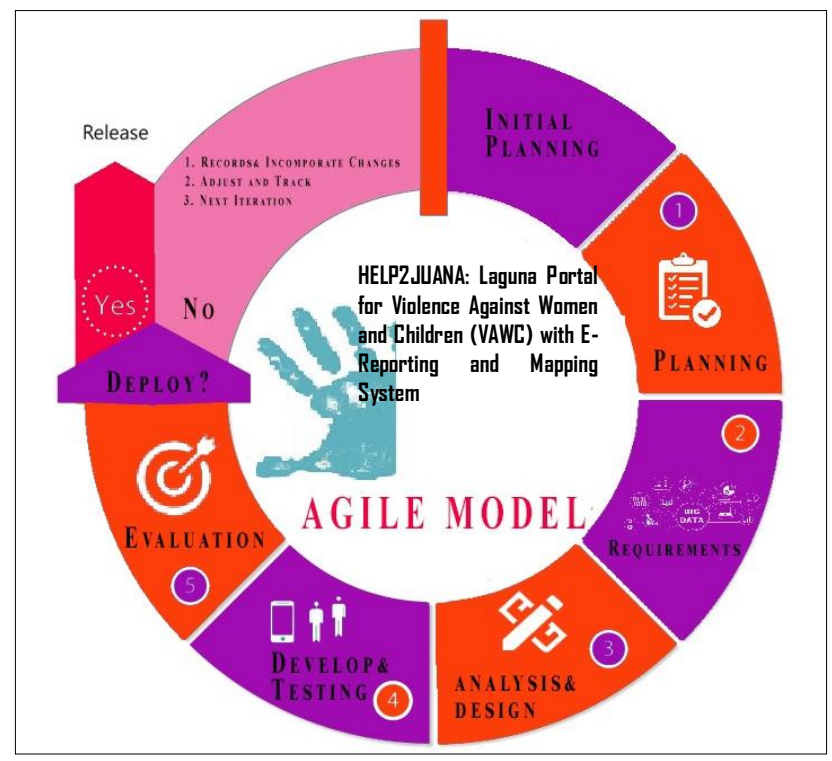

Figure 1. Agile Model of HelpzJuana

In phase 1, gathering data by reading related literature and articles about some application related to crime or VAWC crime, spatial, temporal, web-portal and different method in solving VAWC problems is the initial task of the researcher. An interview to the Provincial Official in Department of the Interior and Local Government (DILG), Provincial Gender and Development (PGAD), Department of Social Welfare and Development (DSWD), Philippine National Police -Women's Desk and Local Government Unit officials was also input to the initialization of the study to know the needs of the communities. Searching possible software for the development of the Web-Portal for the Spatiotemporal Analysis of Violence Against Women and their Children in Laguna and study the function of it to compare the differences of the features. With the following inputs the researcher came up with the topic. The researchers also gathered data for the past report of violence against women and children. The report is from 2014 to 2017. Phase 2, Identifying and finding all the requirements needed in the development of the system, the proponents used some hardware such personal computer, software such as 
phpMyAdmin, WordPress, Apache, MySQL, Adobe Photoshop and Mini Tab. The researcher can also use some mapping application for the features spatiotemporal mapping.

Phase 3, the proponents designed and layout of the application using Data Flow Diagram (DFD) of Admin and User and analyzed the flow of the application base on the function of it that's why proponents came up the conceptual design of the system. Analyze the appropriate features based on the suggestions and recommendation of the VAWC and GAD offices and as well as the identified problems in the literatures. Phase 4 and5, the application undergo testing and evaluation from possible users to determine the possible errors or bugs, if the system is properly working and apply the appropriate solutions to enhance the application capabilities particularly the developers conducted an application testing for the selected individuals. Last phase is the deployment, hence, testing and user's training were the only processes conducted before the system was placed into operation.

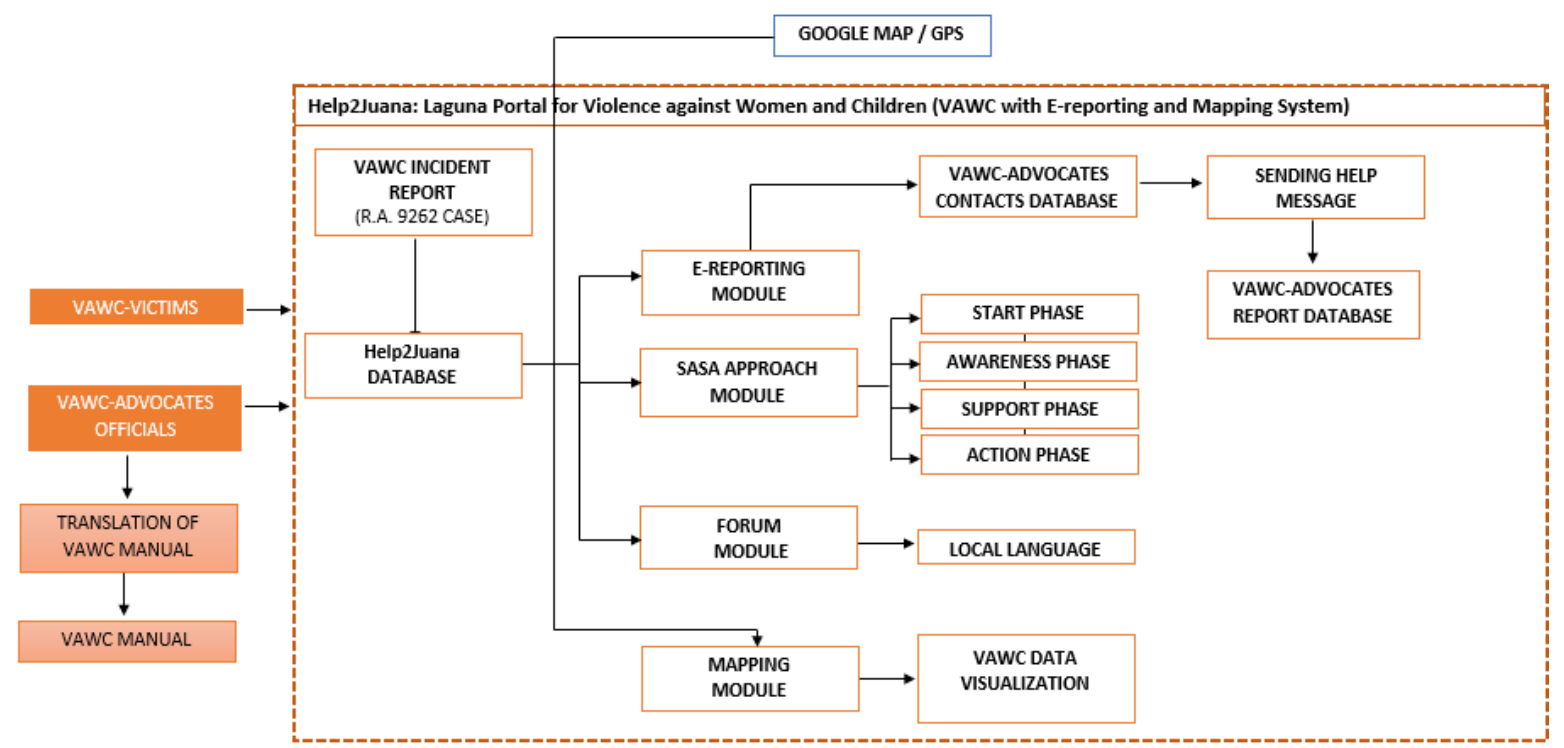

Figure 2. Conceptual Design of Help2Juana

The figure 2 shows the conceptual design of Help2Juana, the system present four modules; E-Reporting Module that provide a reporting tool through which users can log their complaints, SASA Approach Module inside of it is VAWC-related news and articles, display schedules of activities such as trainings, seminars, job opportunities and other programs geared towards helping VAWC victims, Forum Module where users can interact and collaborate with other victims; and Mapping Module for VAWC incident data visualization.

Essential details will be extracted from the collected complaints, which will then be used for mapping out trends or patterns for later visualization and analysis and for sending reports to related government agencies. Data or record of victims has a temporal component, such as the time at which information was taken and when the abuses 
occurred. However, this component is generally less well-supported than the spatial component in GIS and mapping software (Keon et al., 2016). Spatial analysis can be used to help identify some of the victim who report and raise their concerns through ICT channels like websites and mobile devices. This feature is beneficial to the main client of the study which is the Women and the Children. This information can be useful to government authorities and related agencies that respond to and take action against Women and Children victim by the VAWC incidents. The development of a VAW mobile application that offers response strategies and has technology that helps locate victim of abuses has been proposed in a recent study (Balahadia and Bawica, 2017), which inspired the current project.

\section{System Testing and Evaluation}

To assist the testing and evaluation, quota and purposive sampling method in selecting 50 government officials like LGU's, DSWD, DILG, PGAD, and PNP-Women's Desk and 100 female residents in the of each municipalities covered by the 4th district of Laguna such Sta. Cruz, Pagsanjan, Lumban, Kalayaan, Paete, Pakil, Pangil, Siniloan, Famy, and Mabitac.

The researcher also adapted the rubrics utilized by Chen et al. (2006) (see Appendix A) which describe the assessment for the developed system through User Satisfaction indicate the Attitude toward the portal, and Usability Attribute which deals in behavioral intention toward web based application.

The instrument used the Likert Scale to measure the VAWC web-portal shown in Table 1. It includes the criteria of User Satisfaction and Attribute of Usability. The questionnaires of this study will be presented in the Appendix A.

Table1. Likert Scale for System Evaluation

\begin{tabular}{ccl}
\hline Rating & Mean Range & \multicolumn{1}{c}{ Verbal Interpretation } \\
\hline 5 & $4.21-5.00$ & Strongly Agree \\
4 & $3.31-4.20$ & Agree \\
3 & $2.61-3.30$ & Neither Agree or Disagree \\
2 & $1.81-2.60$ & Disagree \\
1 & $1.00-1.80$ & Strongly disagree \\
\hline
\end{tabular}

\section{System Architecture}

Figure 3 shows the flow of the process and the roles of administrator and users in the use of the Anti-VAWC Web Portal. The user needs to register through the administrator in order to create an account where one can report a complaint or incidents of abuse or violence. The five government agencies tasked with anti-VAWC duties are each assigned a system administrator. Data collection and file management will be made available to the administrators from the government agencies. Spatial and temporal analysis of the data 
can generate patterns of triggers of abuse by perpetrators, as well as produce a mapping of different incidents of VAWC.

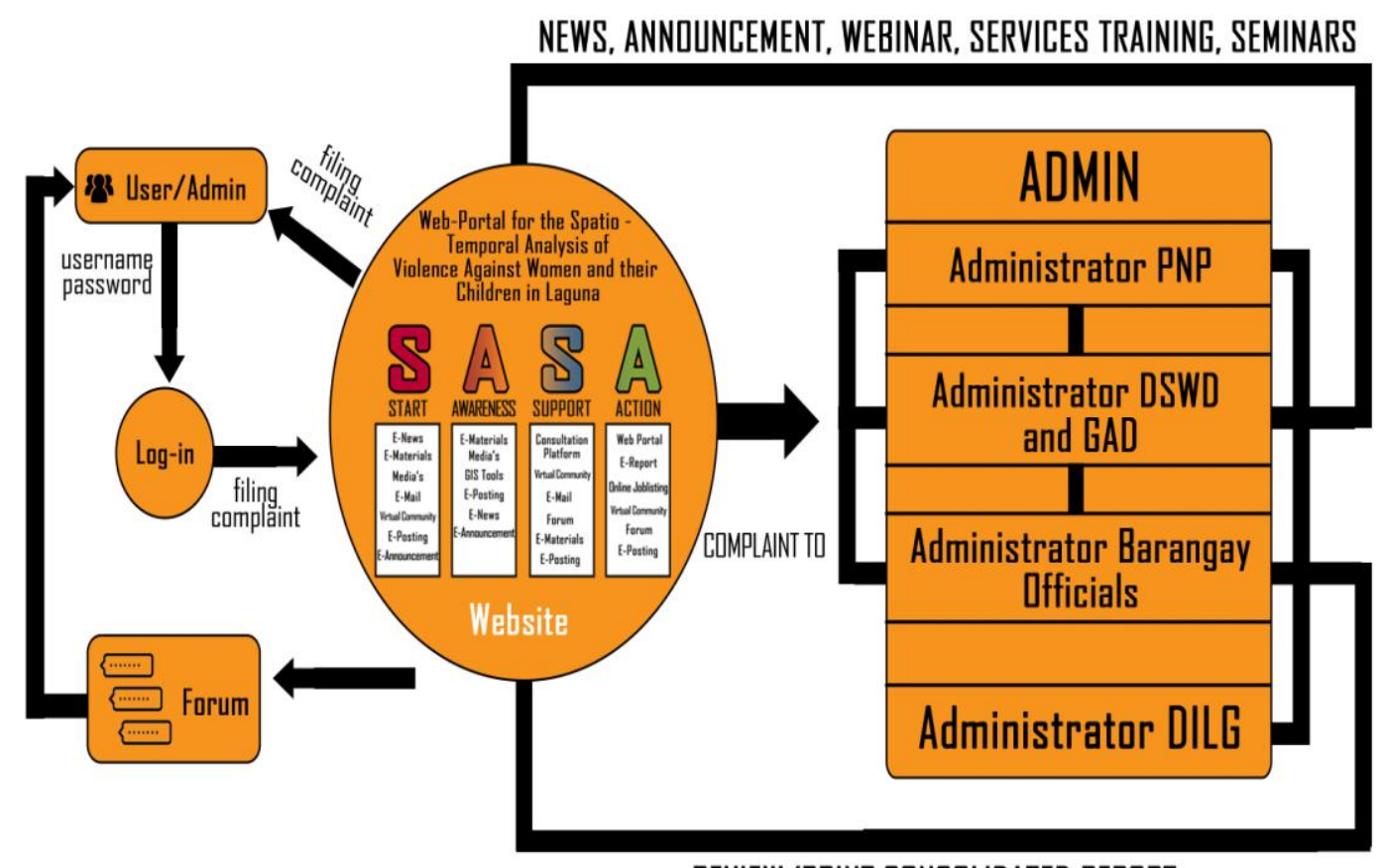

REVIEW/PRINT CONSOLIDATED REPDRT

Figure 3. System Architecture

\section{The Proposed System}

The Help2Juana web portal is managed by the system administrators from the different government agencies (e.g., DSWD-GAD, PNP Women's Desk) who are in control of all the content and features of the system. Figure 4 shows the admin modules where they can perform functions such as posting of announcements and news, registering and creating accounts for new users, generating reports, viewing mapping information, etc. The admin can also add topics to the forum and accept reports or complaints from victims through an electronic messaging feature on the website presented in figure 5 . 


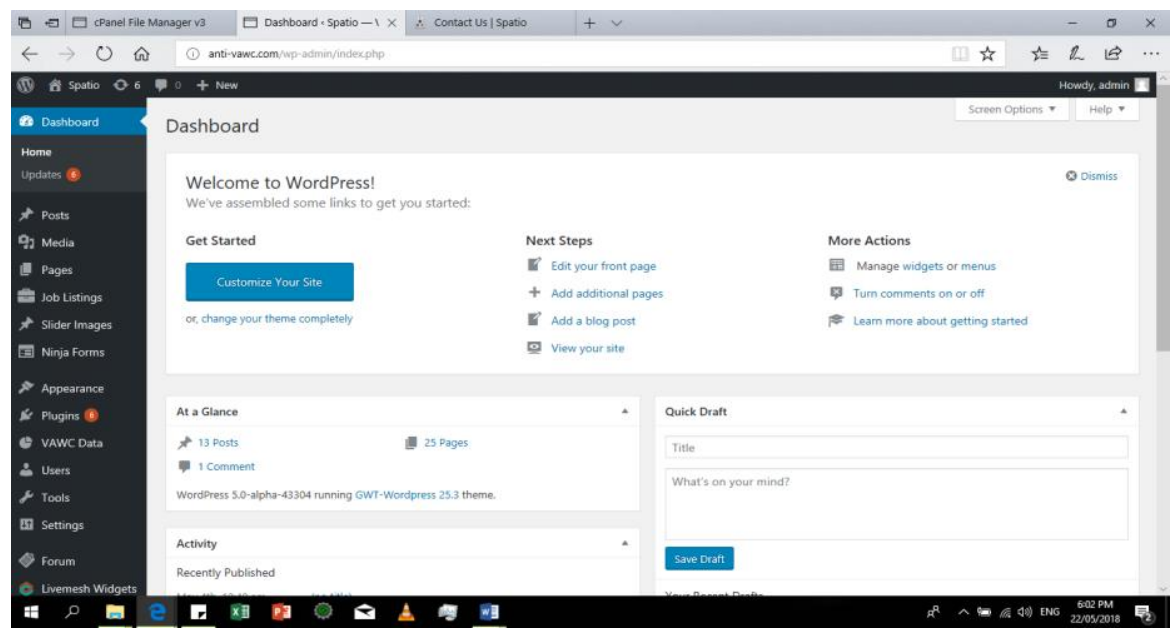

Figure 4. Admin Control Dashboard

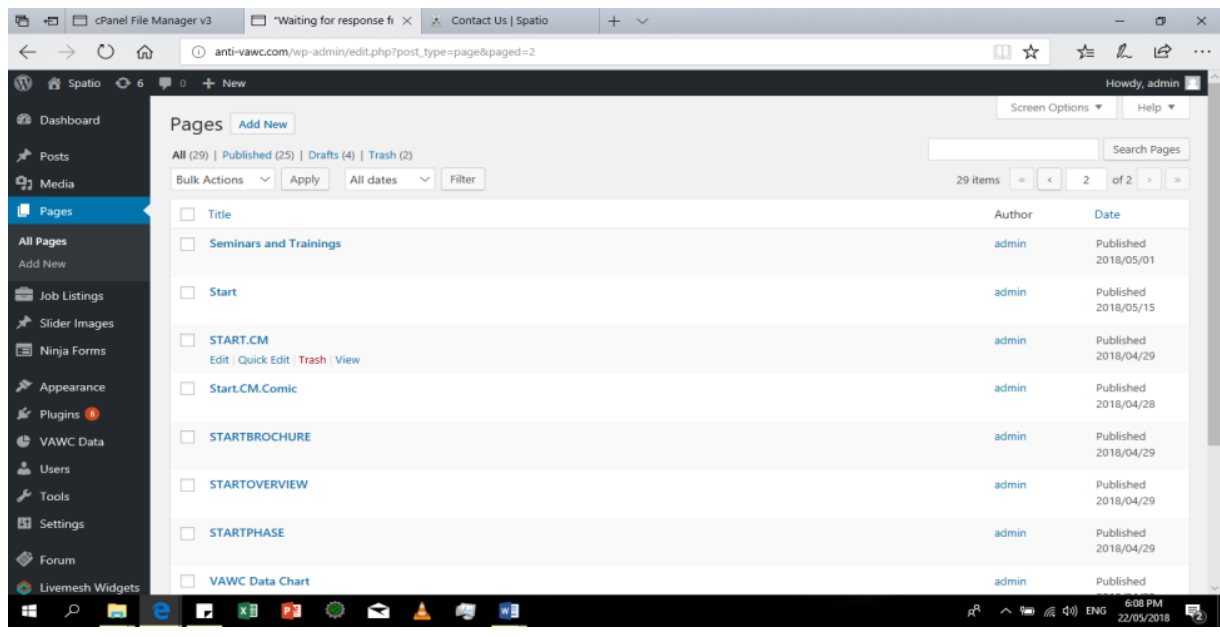

Figure 5. Add New Page in HelpzJuana

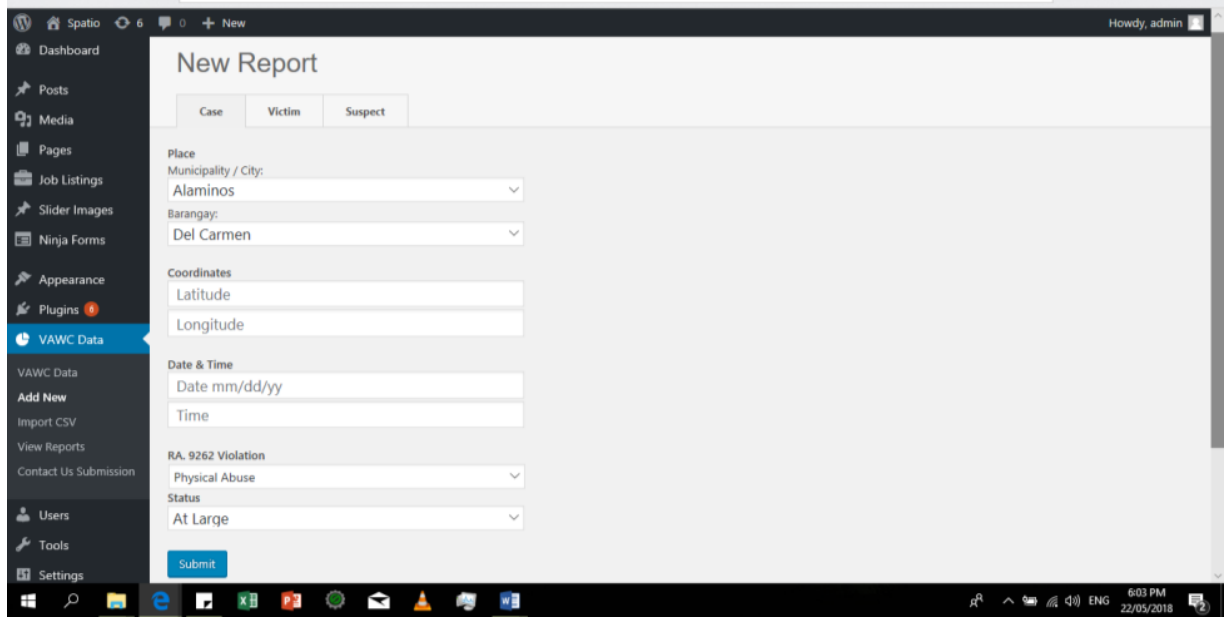

Figure 6. Add New VAWC Report 
In the mapping module (Figure 6), the reports/complaints of victims can be accessed by clicking on the plot report in the map with details including the dates of the incidents and the type of abuse committed by the perpetrator (i.e., physical abuse, psychological abuse, economical abuse, or sexual abuse).

The web portal makes use of data inputted into the system to identify trends and patterns of VAWC incidents in Laguna by means of data visualization see figure 7, geomapping, and data chart. The user can easily retrieve information on VAWC incidents for any municipality and/or city in the province using the integrated mapping services.

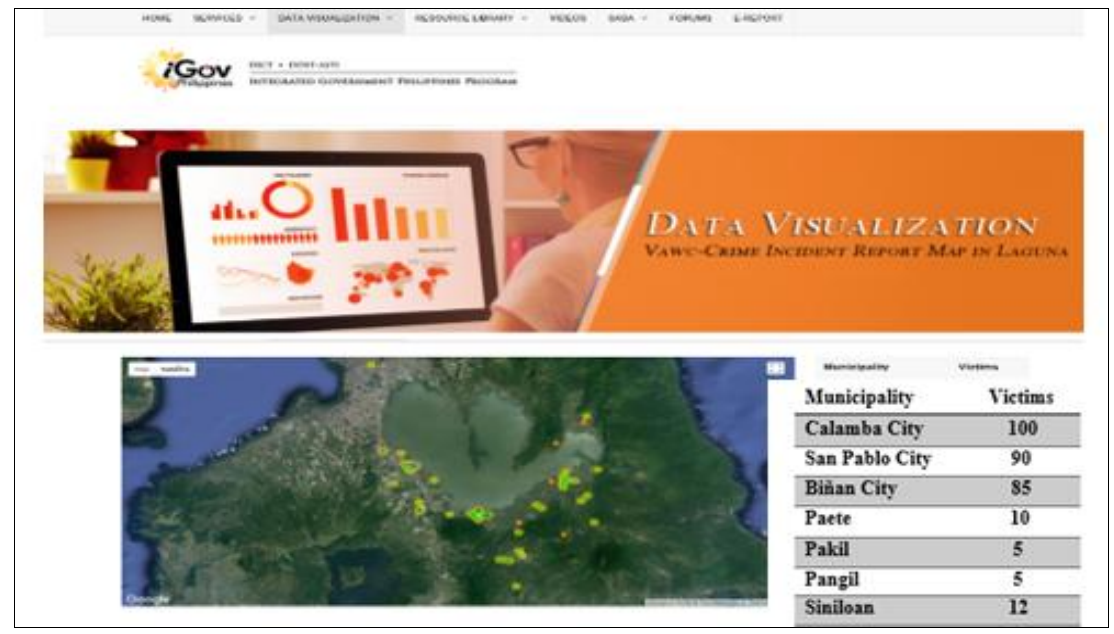

Figure 7. Data Visualization of Help2Juana

The system supports building a supporting relationship between the victims and the government agencies tasked with eradicating VAWC through hosting a forum see figure 8 , which is a virtual community where communication, assistance and support can be provided to the victims. This section of the web portal is only accessible to the government officials and the registered users (VAWC victims). To access the forum, the user needs to log-in using the account credentials provided by the government agencies. Users can also post comments, suggestions and other feedback, as well as share their own story to encourage fellow VAWC victims to stand for their rights.

Registered users have access to all contents of the web portal. They can view different services, news and announcements posted by the admins, as well as view mapping results and VAWC statistics shown in figure 9. Unregistered users are not allowed to join the forum. The system also provides community possible job opportunities especially to women and children presented in figure 10. 


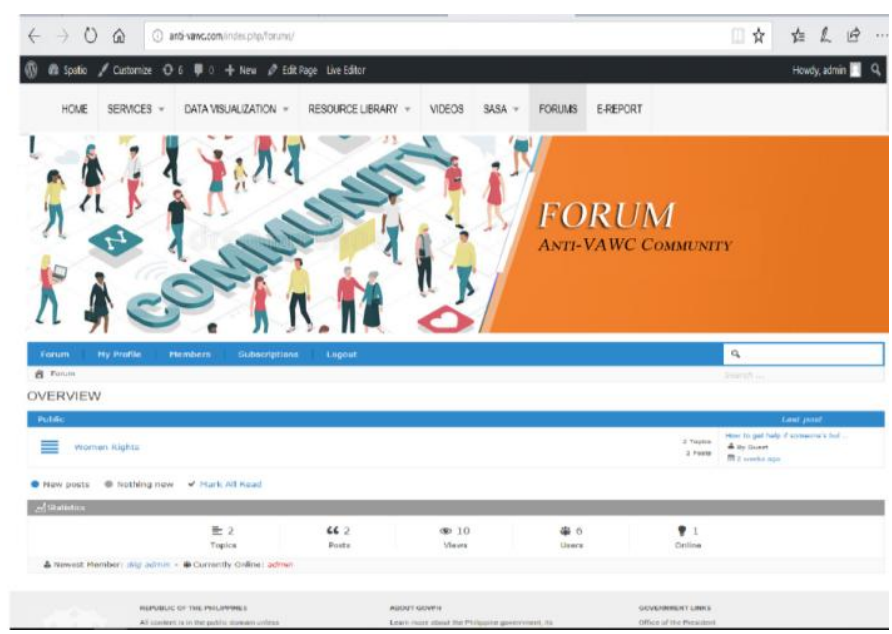

Figure 8. Citizen Complaint and Forum Module

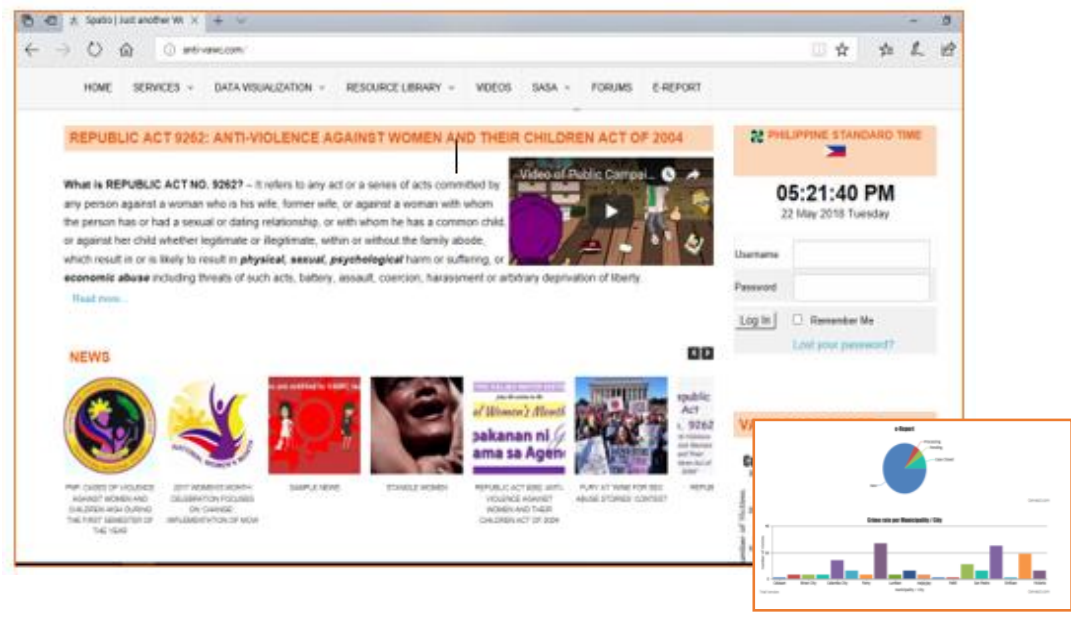

Figure 9. User Access View

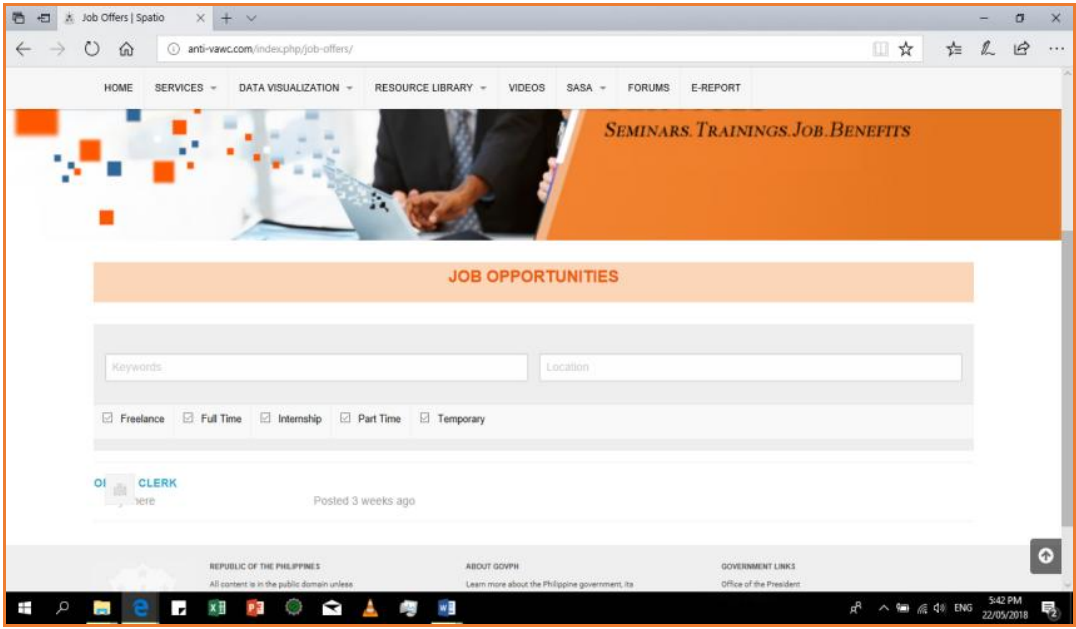

Figure 10. Job Opportunities for VAWC Victim 


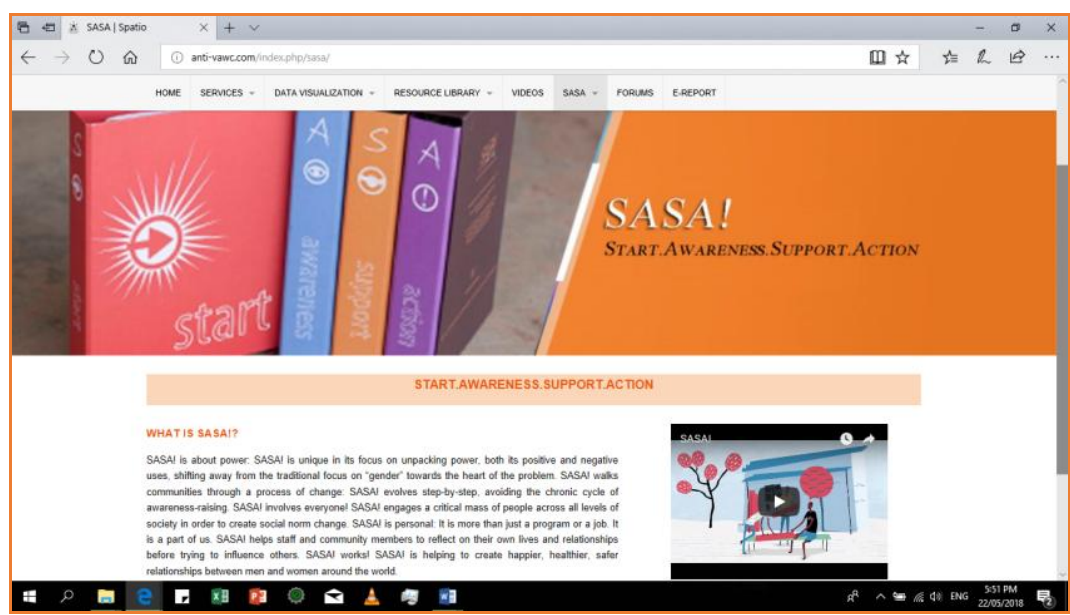

Figure 11. SASA Module

The web portal application utilizes different ICT tools in applying the SASA approach shown in figure 11. The "Start" category involves the use of electronic materials such as brochures, pamphlets, modules, posters, announcements, newsletters, and e-mails, and a virtual community (forum). These materials will entreat users to start thinking about the issue of violence against women and children (VAWC) as a concern that involves the whole community, which will hopefully foster the power within every community member to address the issue. The "Awareness" category is where events, e-posting, media (videos/movie clips), e-news, VAWC-map analysis and other e-materials are utilized in understanding how communities are structured and organized with a view to facilitating the spread of awareness about the issues of VAWC in the community. The "Support" approach focuses on building confidence and courage in the victims through consultation, forum, e-mail, e-materials, e-posting, etc. Lastly, the "Action" approach employs online job listings, forums, online reporting, and virtual communities, among others, in strengthening the connection between community members in order to encourage people to support those who are changing or trying to foster change in their community.

\section{RESULTS AND DISCUSSIONS}

The system was rated by selected respondents of 4th district in Laguna. The evaluation includes User Satisfactions (US) and Attribute of Usability (AU) to assess the possible users specifically the VAWC victims and Government officials related to VAWC will use the developed system.

Table 1 shows a summary of the responses in the User Satisfaction (US) section of the evaluation survey for the Help2Juana web portal. Item US3 (I found it easy to share information about the web application...) had the highest mean score according to responses from the female residents while item US1 (I am completely satisfied in using the web application...) had the highest mean score according to respondents from the government agencies. The average mean of the residents in terms of attitude toward 
Anti-VAWC Web Portal is 4.314 this means that they are strongly agree about the user satisfaction of the system while the government officials have the average mean of 4.188 which mean that they agree that the system user satisfaction. The total mean scores for the User Satisfaction criterion indicate that both female residents and government officials who participated in the survey were highly satisfied with using the HelpzJuana web portal.

Table 1. User Satisfaction: Attitude toward the portal

\begin{tabular}{|c|c|c|c|c|c|c|}
\hline \multirow[b]{2}{*}{$\begin{array}{l}\text { Satisfaction } \\
\text { Attitude toward the Anti-VAWC }\end{array}$} & \multicolumn{3}{|c|}{ Residents } & \multicolumn{3}{|c|}{ Government Officials } \\
\hline & Mean & Rank & Interpretation & $\begin{array}{c}\text { Mea } \\
n\end{array}$ & Rank & Interpretation \\
\hline $\begin{array}{l}\text { US1: I completely satisfied in using the } \\
\text { Web Application for Violence Against } \\
\text { Women Support Services. completely } \\
\text { satisfied in using the Web Application } \\
\text { for Violence Against Women Support } \\
\text { Services. }\end{array}$ & $4 \cdot 33$ & 2 & $\begin{array}{l}\text { Strongly } \\
\text { Agree }\end{array}$ & 4.36 & 1 & $\begin{array}{l}\text { Strongly } \\
\text { Agree }\end{array}$ \\
\hline $\begin{array}{l}\text { US2: I feel very confident in using the } \\
\text { Web Application for Violence Against } \\
\text { Women Support Services. }\end{array}$ & 4.26 & 5 & $\begin{array}{l}\text { Strongly } \\
\text { Agree }\end{array}$ & 4.14 & 4 & Agree \\
\hline $\begin{array}{l}\text { US3: I found it easy to share } \\
\text { information about the Web Application } \\
\text { for Violence Against Women Support } \\
\text { Services. }\end{array}$ & 4.38 & 1 & $\begin{array}{l}\text { Strongly } \\
\text { Agree }\end{array}$ & 4.12 & 5 & Agree \\
\hline $\begin{array}{l}\text { US4: I can accomplish the task quickly } \\
\text { using this procedure. }\end{array}$ & 4.29 & 4 & $\begin{array}{l}\text { Strongly } \\
\text { Agree }\end{array}$ & 4.16 & 2.5 & Agree \\
\hline $\begin{array}{l}\text { US5: I believe that from using the Web } \\
\text { Application for Violence Against } \\
\text { Women Support Services will increase } \\
\text { the quality of services. }\end{array}$ & $4 \cdot 31$ & 3 & $\begin{array}{l}\text { Strongly } \\
\text { Agree }\end{array}$ & 4.16 & 2.5 & Agree \\
\hline AVERAGE & $4 \cdot 314$ & & & 4.188 & & \\
\hline
\end{tabular}

Table 2 shows the summary statistics in the Attribute of Usability (AU) criterion of the evaluation survey. The respondents evaluated the degree to which the residents and government officials perceived the likelihood of adopting or using the anti-VAWC web portal. Both parties gave the system high scores in all five attributes of the average score of both residents and government officials depicts agreement in VAWC website, both respondents show likelihood in adopting VAWC web portal. The 4.29 average mean of the residents strongly agree in terms of behavioral intention while the government officials have the average mean of 4.196 which mean they are agree. AU criterion indicating a highly positive attitude towards web-based learning that the HelpzJuana system offers. 
Table 2. Usability Attribute: Behavioral Intention toward web-based application

\begin{tabular}{|c|c|c|c|c|c|c|}
\hline \multirow{2}{*}{$\begin{array}{l}\text { Attribute of Usability } \\
\text { Behavioral intentions toward } \\
\text { web-based learning }(\mathrm{BI})\end{array}$} & \multicolumn{3}{|c|}{ Residents } & \multicolumn{3}{|c|}{ Government Officials } \\
\hline & Mean & Rank & Interpretation & Mean & Rank & Interpretation \\
\hline $\begin{array}{l}\text { AU1: It easy to interact with the } \\
\text { Web Application for Violence } \\
\text { Against Women Support Services }\end{array}$ & 4.35 & 1 & Strongly Agree & 4.26 & 2 & $\begin{array}{l}\text { Strongly } \\
\text { Agree }\end{array}$ \\
\hline $\begin{array}{l}\text { AU2: The procedure through the } \\
\text { Web Application for Violence } \\
\text { Against Women Support Services }\end{array}$ & 4.25 & 4.5 & Strongly Agree & 4.4 & 1 & $\begin{array}{l}\text { Strongly } \\
\text { Agree }\end{array}$ \\
\hline $\begin{array}{l}\text { AU3: I found it easy to decide } \\
\text { which the case need to be }\end{array}$ & 4.25 & 4.5 & Strongly Agree & 4.14 & 4 & Agree \\
\hline $\begin{array}{l}\text { AU4: I found the various } \\
\text { functions in this system were well } \\
\text { integrate }\end{array}$ & 4.29 & 3 & Strongly Agree & 4 & 5 & Agree \\
\hline $\begin{array}{l}\text { AU5: I think that I would like to } \\
\text { use this system always }\end{array}$ & $4 \cdot 31$ & 2 & Strongly Agree & 4.18 & 3 & Agree \\
\hline AVERAGE & 4.29 & & & 4.196 & & \\
\hline
\end{tabular}

\section{CONCLUSIONS AND RECOMMENDATIONS}

The results of the evaluation suggest the high viability of using the HelpzJuana web portal as a tool in the campaign to end violence against women and their children. The high acceptability scores that the respondents from the participating government agencies and the women's community indicates their readiness to adopt and use the system in the said campaign. This positive attitude towards the project can make HelpzJuana useful in getting insights for planning VAWC prevention programs and policies, by taking advantage of the empirical data that are provided by the statistical tools integrated into the system. These tools help determine the types and frequency of abuses and map out locations with high percentages of VAWC incidents, among others.

It is therefore recommended that the LGU's and the Women's Community in Laguna consider employing the HelpzJuana system in the near future, to test out its capabilities in facilitating and supporting anti-VAWC programs. Other features related to improving government procedures can be added in the process to improve the quality of response to VAWC incidents. Inclusion of other features such as webinars and job notifications via e-mail and SMS may be considered in future developments.

\section{IMPLICATIONS}

Once the study has been implemented it will benefit the women and children who experiencing the different violence inside their home or violence cause by their relatives. They can easily seek help and report the VAWC incident without shame. And the Women, Children and Government official will be knowledgeable about the legislation of R.A. 9262. The study is beneficial also to the Province of Laguna especially to the offices of 
PGAD, PNP-Women Desk, DILG, DSWD and LGU's to improve the following; VAWC incident report gathering, consolidated report management, monitoring the VAWC incident in Laguna using spatiotemporal Mapping and extending help to the VAWC victim using the web portal.

\section{REFERENCES}

Balahadia, F. F., \& Bawica, J. M. (2017). Developing mobile application for public awareness on violence against women. Journal of Engineering and Applied Sciences, 12(9), 8518-8522.

Chen, I. J., Yang, K.-F., Tang, F.-I., Huang, C.-H.,\& Yu, S. (2006). Applying the technology acceptance model to explore public health nurses' intentions towards web-based learning: A cross-sectional questionnaire survey. International Journal of Nursing Studies, 45(6), 869-868. doi: 10.1016/j.ijnurstu.2006.11.011

Evers, L. (2017). Innovative approach to combating violence against women and girls. Retrieved from https://www.trocaire.org/news/innovative-approach-combatingviolence-against-women-and-girls

Galacio, A. G. (May 21, 2006). Legal Updates: RA 9262 or the Anti-Violence Against Women and their Children Act of 2004. Retrieved from https://pcw.gov.ph/law/republic-act9262

Inter-Agency Council on Violence Against Women and Their Children (IACVAWC). (2004). Strategic plan of the IACVAWC 2007-2010. Retrieved from https://www.pcw.gov.ph/focus-areas/violence-against-women/initiatives/iacvawc

Keon, D., Pancake, C. M., Steinberg, B., \& Yeh, H. (2016). Performance- based tsunami engineering via a web-based GIS data explorer. Journal of Disaster Research, 11(4), 624633.

Lobusta, M., Molod, C., \& Santos, A.S. (2014). R.A. 9262: Anti-Violence against Women and Children Law: An Assessment (Unpublished manuscript). San Beda University, Manila, Philippines.

Philippine Commission on Women. (2009). Violence against women (VAW). Retrieved from: http://cws.up.edu.ph/wp-content/uploads/RA-9710-Magna-Carta-ofWomen.pdf

Taymor, E. (n.d.). Philosophie: Agile Handbook. Retrieved from http://agilehandbook.com/agile-handbook.pdf

UNICEF. ( 2014). Hidden in plain sight: A statistical Analysis of violence against children. Retrieved from http://files.unicef.org/publications/files /Hidden_in_plain_sight_statistical_analysis_EN_3_Sept_2014.pdf

United Nations. (1993). Declaration of the elimination of violence against women, Resolution 48/104. Retrieved from http://www.un.org/documents/ga/res/48/a48r104.htm

Women Working Together to Stop Violence Against Women (WWTSVAW). (2009). Breaking the silence,seeking justice in intimate partner violence in the Philippines : A review on the implementation of Republic Act 9262 Or the Anti-Violence against Women and their Children Act of 2004. Retrieved from http://www.amnesty.org.ph/wp-content/uploads/2014/04/Breaking_the_Silence.pdf 


\section{APPENDIX A. QUESTIONNAIRES}

RESPONDENT'S INFORMATION

(Please supply the information for reference purposes)

Name (Optional):

E-mail Address:

Address:

Age:

Sex:

Cell No.:

DIRECTION: Kindly provide honest answers to the given topics. Please read each topic carefully and check $(v)$ the box provided that best describes your notion about the them. Please do not leave any items blank.

SCALE

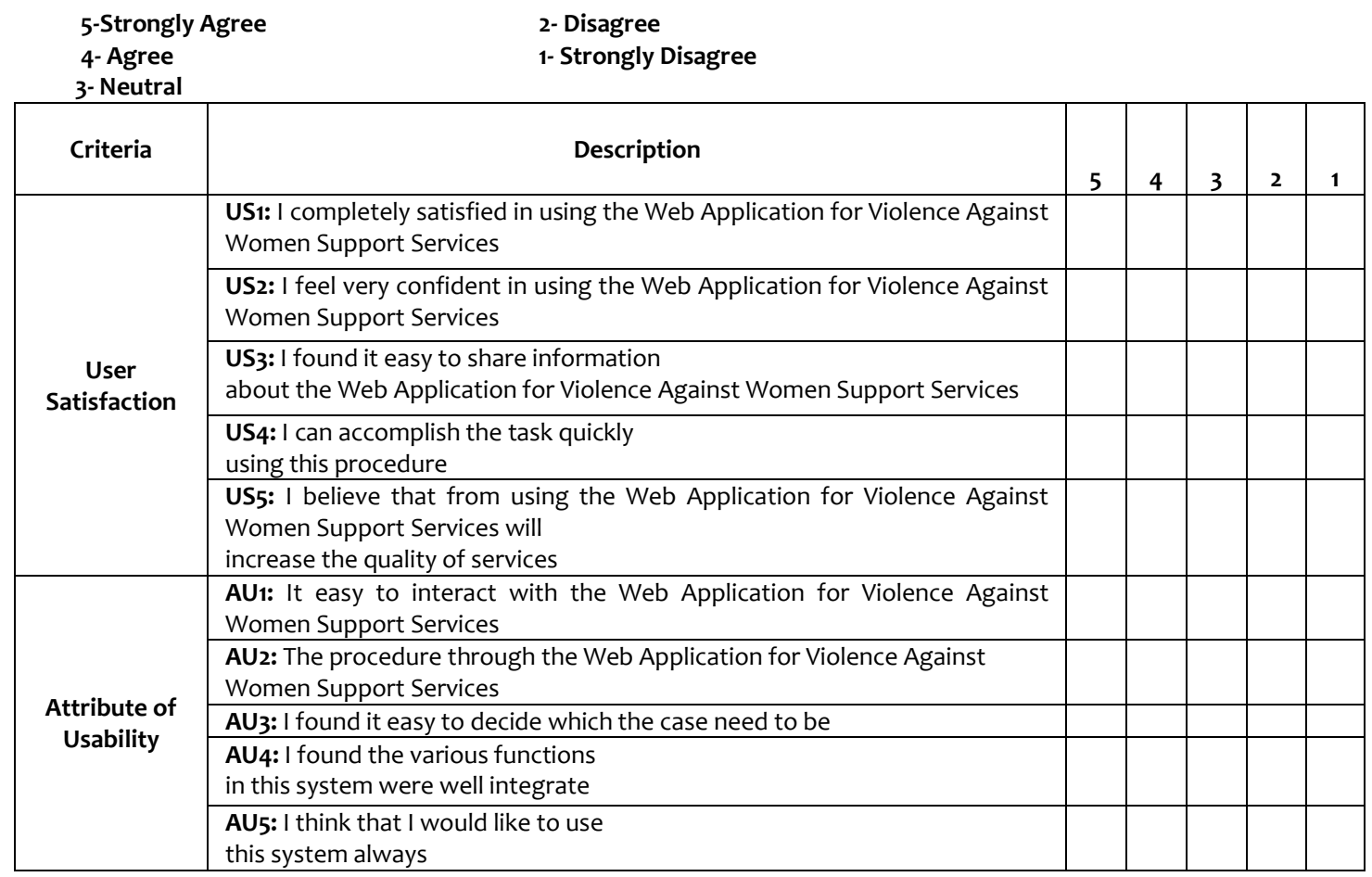

